\title{
Adsorption Behavior of Cationic Dye on Bentonite Functionalized With 3-aminopropyltriethoxysilane
}

\author{
MAZOURI BELHADRI ( $\sim$ bhmazouri@yahoo.fr) \\ Université d'Oran1 Ahmed Ben bella \\ Adel Mokhtar \\ Université d'Oran1 Ahmed Ben bella \\ Abdelkader Bengueddach Bengueddach \\ Université d'Oran1 Ahmed Ben bella \\ mohamed sassi \\ Université d'Oran1 Ahmed Ben bella
}

\section{Research Article}

Keywords: Bentonite, 3-aminopropyltrimethoxysilane, Adsorption, Methylene blue

Posted Date: August 24th, 2021

DOI: https://doi.org/10.21203/rs.3.rs-826750/v1

License: (9) This work is licensed under a Creative Commons Attribution 4.0 International License.

Read Full License 


\title{
Adsorption behavior of cationic dye on bentonite functionalized with 3-aminopropyltriethoxysilane
}

\author{
Mazouri Belhadri*1, ${ }^{2}$, Adel Mokhtar ${ }^{1}$, Abdelkader Bengueddach ${ }^{1}$ and Mohamed Sassi $^{1}$ \\ ${ }^{1}$ Laboratoire de Chimie des Matériaux L.C.M, Département de Chimie, Faculté des Sciences Exactes et \\ Appliquées, Université d'Oran1 Ahmed Ben bella, BP 1524, El-Mnaouer, 31000 Oran, Algeria \\ ${ }^{2}$ Laboratoire de Rhéologie, Transport des fluides complexes, Département d'Hydraulique, Faculté \\ d'Architecture et Génie Civil, Université des Sciences et de la Technologie Mohamed Boudiaf, BP 1505 \\ El-Mnaouer, 31000 Oran. Algerie \\ Corresponding author: MazouriBelhadri \\ E-mail addresses: bhmazouri@yahoo.fr; mazouri.belhadri@univ-usto.dz
}

\begin{abstract}
The current study focused on the modification of Algerian bentonite clay (Bent) with the product of hydrolysis of 3-aminopropyltriethoxysilane (APTES) using the intercalation process. The modified clay (Bent-APTES) was investigated as an adsorbent solid for methylene blue dye (MB) removal from wastewater.The Bent-APTES was characterized by X-ray diffraction (XRD), chemical analyses, Fouriertransform infrared spectroscopy (FTIR) and thermogravimetric analysis (TGA). The cationic exchange capacity was also determined. Several adsorption parameters were evaluated on the adsorption performance. The results showed that the equilibrium adsorption data was found to fit better to the Langmuir adsorption model, and the adsorption capacity for the removal of MB on Bent-APTES was $217.39 \mathrm{mg} \mathrm{g}^{-1}$. The kinetic process of adsorption could be described by the pseudo-second order model. Consequently, the modified clay could be served as an efficient adsorbent for cationic dyes in wastewater treatment.
\end{abstract}

Keywords: Bentonite;3-aminopropyltrimethoxysilane;Adsorption;Methylene blue.

Authors contribution : All the authors contributed to the writing of the paper. All the authors read and approved the manuscript.

\section{Declarations}

Funding: The authors received no specific funding for this work

Conflicts of interest/Competing interests: The authors declare that the research was conducted in the absence of any commercial or financial relationships that could be construed as a potential conflict of interest. 


\section{Introduction}

With the rapid development of human society, harmful dyes are getting one among the most sources of pollution and represent a major environmental concern (mith et al. 2016). The presence of dyes in water, even at low concentrations, is very harmful to living beings (Weng et al. 2007 et al.; Borhade et al. 2017). Methylene blue, a cationic dye, is one sort of the water-soluble dyes with high chromaticity which is extensively utilized in chemical indicators, dyes, biological stains and medecines. It is quite visible and stable in water at room temperature (Russo et al. 2016). As an synthetic dye, methylene blue is largely widely used in many fields, including paper, food processing, plastics and printing. All of them are closely linked to our life. Therefore, dyes removal from wastewater is a matter of utmost urgency. there are several methods to remove dyes from effluents, such as flocculation, membrane, electrochemical methods, coagulation and adsorption (Mondal et al. 2013; Vergili et al. 2012; Verma et al. 2012). Among different ways, adsorption is an equilibrium separation process that removes dyes from effluents effectively (Elmoubarki et al. 2015; Yagub et al. 2014).

Clay minerals are widespread, low cost and environmentally friendly materials which demonstrated their efficiency in the remediation of the environmental pollution (Belhadri et al. 2019). Current studies have established that the adsorption capability can be improved by modification of adsorbents (Kausar et al. 2018).

Chemical modification of silica surface is an area of intense interest from both fundamental and practical points of view. Bentonite (Bent) is a clay mineral of group having silica tetrahedral sheets layered between alumina octahedral sheets. Due to isomorphic substitution within the layers (for example, $\mathrm{Al}^{3+}$ replaced by $\mathrm{Mg}^{2+}$ or $\mathrm{Fe}^{2+}$ in the octahedral sheet; $\mathrm{Si}^{4+}$ replaced by $\mathrm{Al}^{3+}$ in the tetrahedral sheet), the clay layer is negatively charged which is counterbalanced by the cations located in the interlayer space. The hydration of inorganic cations on the exchange sites causes its surface to be hydrophilic (Shen et al. 2007). It is frequently exploited to get nanocomposites and environmental materials due to its aspect ratio (Zhang et al. 2006; Ianchis et al. 2012; Huskić et al. 2013), capacity for swelling (He et al. 2005) and ion exchange, softness, high solvent resistance, good mechanical strength and high capacity for delamination (Bertuoli et al. 2014).

Silylation was proven an efficient method to modify the surfaces of clay minerals (Su et al 2012; Zhang et al. 2006, Ruiz-Hitzky and Fripiat 1976; Tao et al. 2011).

The linkage between organic components and clay via covalent bonds enables a durable immobilization of the reactive organic groups, avoiding their leaching in the surrounding medium when the silane grafted clays are used in solutions [ $\mathrm{Su}$ et al 2012; Waddell et al. 1981].

This paper reports changes in the structure of an Algerian bentonite clay which has been intercalated with a 3-aminopropyltriethoxysilane, to our knowledge this clay (Algerian bentonite) has never been modified by this molecule.

X-ray diffraction (XRD), chemical analysis, thermogravimetric analysis (TGA) and Fourier transform infrared (FTIR) spectroscopy were employed to characterize the modified clay minerals. The objective of the research is to see the behavior of this clay by the modification by silylation procedure and its application in the adsorption of MB from aqueous solutions. The effect of various operational parameters such as the initial $\mathrm{MB}$ dye concentration, $\mathrm{pH}$, temperature and the adsorbent dosage on adsorption was 
studied. Different isotherm models were investigated for fitting the adsorption equilibrium data, and also the kinetics of adsorption process were also studied.

\section{Materials and methods}

\section{Materials}

All the chemicals and reagents used were of analytical grade. Algerian clay sample (Bent) used in this study was taken from a mine in Magnia region, northeastern Algeria. The silane used in this research is 3aminopropyltriethoxysilane (APTES). The chemical formula of APTES is $\mathrm{NH}_{2}-\mathrm{CH}_{2}-\mathrm{CH}_{2}-\mathrm{CH}_{2}-\mathrm{Si}$ $\left(\mathrm{OCH}_{3}\right)_{3}$.

\section{Characterization methods}

Powder X-ray diffraction (XRD) patterns of the clays were obtained using a Bruker AXS D-8 diffractometer with $\mathrm{Cu} \mathrm{K} \alpha$ radiation in the $2 \theta$ range from $5^{\circ}$ to $70^{\circ}$. The morphological features of clays were investigated using a scanning electron microscope (PHILIPS XL30) with an accelerating voltage $20 \mathrm{kV}$. The Fourier transform infrared (FTIR) spectra were obtained by the KBr method using a FT/IR4200 type FTIR spectrometer. The chemical composition of the samples was performed by X-ray fluorescence using a Philips PW2540 Magix spectrophotometer yielding the percentage of each constituting element in weight. The thermal analysis (TG-DTA) was performed in air using a start Pyris DTA-TGA analyzer. All the samples were heated to $1000^{\circ} \mathrm{C}$ at heating rate of $5^{\circ} \mathrm{C} \mathrm{min}{ }^{-1}$. For aqueous solution analysis, a Hanna 210 microprocessor $\mathrm{pH}$ meter was used for $\mathrm{pH}$ value measurements.

\section{Preparation of the pillared clay}

For preparing pillared clay (Bent-APTES), clay was sedimented to eliminate the fraction superior to $2 \mu \mathrm{m}$. The obtained material is named Bent.

The preparation of pillaring solutions is as follows:

First, $20 \mathrm{~g}$ of 3-aminopropyltrimethoxysilane and $60 \mathrm{ml}$ of methanol are mixed with stirring at room temperature. Next, $6 \mathrm{ml}$ of $\mathrm{HCl}(16 \%)$ are added dropwise. After this, the solution is stirred for 27 h. 300 $\mathrm{ml}$ of acetone are added and the solution heated to reflux for $1 \mathrm{~h}$. Finally, cooled to room temperature while stirring for $3 \mathrm{~h}$. The final $\mathrm{pH}$ was 9.7. This solution is stored in dark for 2 hours. In fact, this treatment leads to a condensation of the silanes into polysiloxanes.

The intercalated clay was obtained by adding dropwise the amount of pillaring solution ( $4 \mathrm{~mL} / \mathrm{min})$ to the sedimented clay in suspension $(5 \mathrm{~g}$ in $1670 \mathrm{~mL}$ of deionized water) (Fetter et al. 1994). The modified clay was centrifuged and washed with deionised water $(2 \mathrm{~L} / \mathrm{g})$ and dried in thin layers in air. The sample was reference Bent-APTES (scheme 1). 


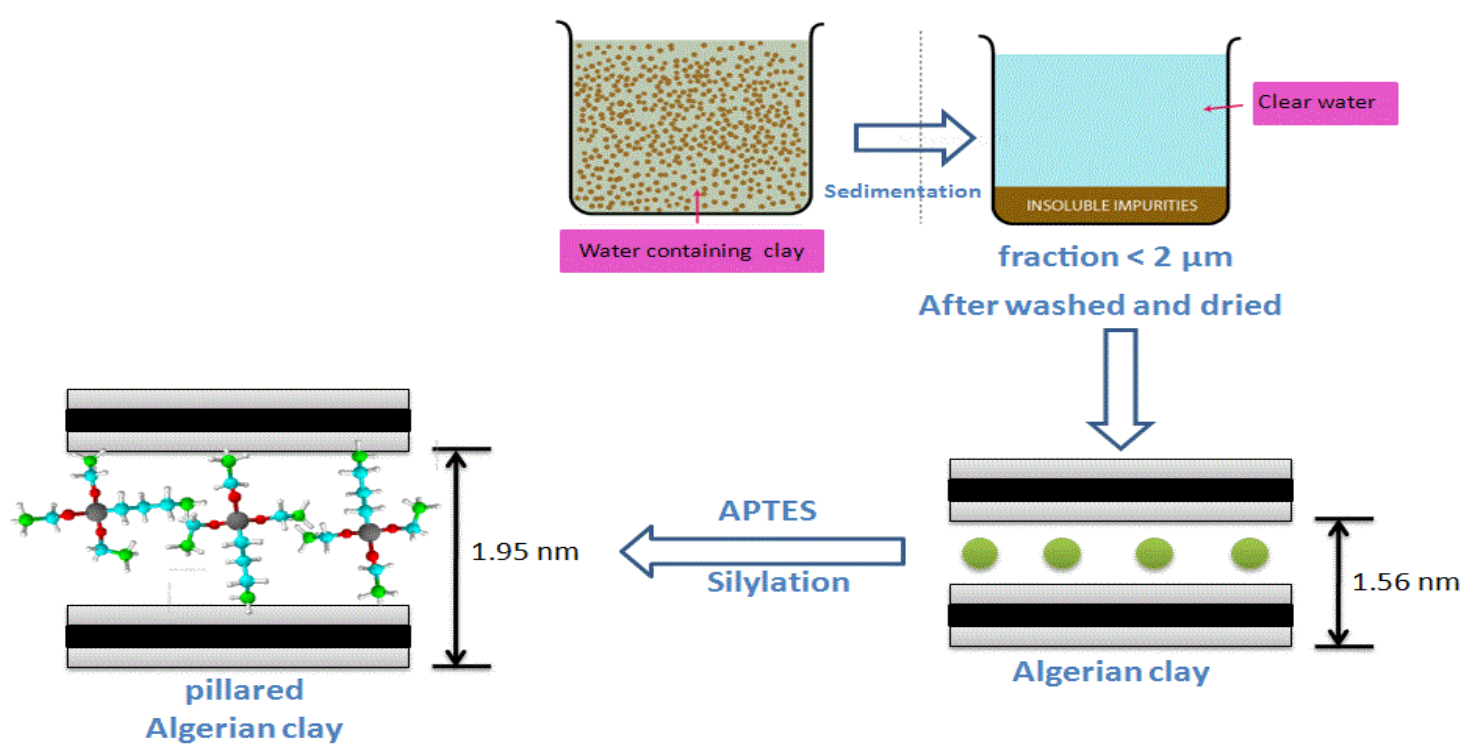

Scheme 1 Silylation of Algerian bentonite with APTES

\section{Determination of cation-exchange capacity (CEC)}

The cation exchange capacity (CEC) was determined with the conductimetric method described in previous work (Peech et al. 1961; Chiu et al. 1990).

\section{Adsorption studies}

\section{Adsorbate and other chemicals}

Analytical grade of MB dye was selected as the model organic cationic dye in this study. The molecular formula of $\mathrm{MB}$ dye is $\mathrm{C}_{16} \mathrm{H}_{18} \mathrm{ClN}_{3} \mathrm{~S}$ with the molecular weight of $319.851 \mathrm{~g} / \mathrm{mol}$.

A stock solution of dye having a concentration of $1000 \mathrm{mg} / \mathrm{L}$ was prepared by dissolving appropriate amount of MB dye powder in $1 \mathrm{~L}$ deionized water, and then it was diluted to the desired concentration of each experiment. The UV/VIS (V-670) spectrophotometer was used to measure the concentration of MB dye in solution at wave length of $\lambda \max =665 \mathrm{~nm}$.

The $\mathrm{pH}$ solution was adjusted using reagent grade $\mathrm{HCl}$ and $\mathrm{NaOH}$.

\section{Adsorption experiments}

All the adsorption experiments were done in triplicate under similar conditions. The experimental variables examined were contact time, bentonite concentration in suspension, $\mathrm{pH}$ of suspension and MB concentration. The experiments were carried out as follows: a $0.5 \mathrm{~g}$ of dry adsorbent Bent-APTES was added to $500 \mathrm{ml}$ of aqueous $\mathrm{MB}$ solution of specific concentration and then stirred at room temperature at different time intervals $(0-160 \mathrm{~min})$. The resultant solution was centrifuged and the residual MB concentration was measured by a UV spectrophotometer to determine the amount of MB uptake. In this 
study, the adsorption experiments were performed in the initial $\mathrm{pH}$ range between 2 and 9, in these cases, $\mathrm{pH}$ of the solution was adjusted to the desired value by adding $\mathrm{HCl}$ or $\mathrm{NaOH}$ as required. The effect of adsorbent dosage on MB adsorption was studied by increasing the amounts of adsorbent from $0.25 \mathrm{~g}$ to 4.0 g. To establish the adsorption isotherms, this study was carried out with different initial MB concentrations varying from $5 \mathrm{mg} / \mathrm{L}$ to $340 \mathrm{mg} / \mathrm{L}$.

The adsorbent MB uptake, per unit mass of clay at time $t, q \mathrm{t}(\mathrm{mg} / \mathrm{g})$ was evaluated by the following equations:

$$
\begin{aligned}
& q_{t}=\left(C_{0}-C_{t}\right) \frac{V}{m} \\
& q_{e}=\left(C_{0}-C_{e}\right) \frac{V}{m}
\end{aligned}
$$

where $\mathrm{qt}$ and $q_{e}(\mathrm{mg} / \mathrm{g})$ are adsorption amount of the dye at time $\mathrm{t}$ and equilibrium, $\mathrm{C}_{0}, \mathrm{C}_{\mathrm{t}}$ and $C_{e}\left(\mathrm{mg} \mathrm{L}^{-1}\right)$ are the concentration of MB solution at initial, time $\mathrm{t}$ and equilibrium, respectively, $\mathrm{V}(\mathrm{L})$ is the volume of MB solution, $\mathrm{m}(\mathrm{g})$ corresponds to dosage of adsorbent.

\section{Result and discussion}

\section{Characterization of the adsorbent}

\section{Composition of clays}

The chemical analysis (Table 1) shows an increase in the silicon and oxygen content and the complete disappearance of calcium, sodium and potassium for the Bent- APTES intercalated clay. These results confirm the operation of the exchange of cations $\left(\mathrm{Na}^{+}, \mathrm{Ca}^{2+} \mathrm{K}^{+}\right)$by the organosilicon oligomer species.

Table 1. Chemical composition, in mol\% of oxides, of samples Bent and Bent- APTES.

\begin{tabular}{llllllll}
\hline Samples & $\mathrm{SiO}_{2}$ & $\mathrm{Al}_{2} \mathrm{O}_{3}$ & $\mathrm{Fe}_{2} \mathrm{O}_{3}$ & $\mathrm{CaO}$ & $\mathrm{MgO}$ & $\mathrm{Na}_{2} \mathrm{O}$ & $\mathrm{K}_{2} \mathrm{O}$ \\
\hline Bent & 44.42 & 14.65 & 2.83 & 0.77 & 3.43 & 4.05 & 1.92 \\
\hline Bent- APTES & 81.92 & 17.07 & 2.27 & 0.00 & 2.78 & 0.00 & 0.00 \\
\hline
\end{tabular}

\section{X-ray diffraction (XRD)}

The X-ray diffraction pattern of the clay and the modified clay are reported in Fig. 1. The basal spacing for natural clay Bent is $1.56 \mathrm{~nm}$. After silylation, the value increases to $1.95 \mathrm{~nm}$, indicating that silane has entered the Bent galleries (Fetter et al. 1994, Jlassi et al. 2017; Su et al. 2012) However, the new reflection around $8^{\circ}(2 \theta)$ is attributed to the (002) reflection of the silylated product, similar to those of the cationic surfactant modified montmorillonite ( $\mathrm{Su}$ et al. 2012; He et al. 2004). According to previous works (Chen et al. 2013), the height of the interlayer space can be estimated with the basal spacing and 
the thickness of the sheet of phyllosilicate with value of $0.96 \mathrm{~nm}$. The gallery height of the bentonite was estimated, from the observed basal spacing, to be $0.96 \mathrm{~nm}$ and by calculating the interlayer space height for modified clay $(0.99 \mathrm{~nm})$. The value is large enough to accommodate the 3aminopropyltrimethoxysilane molecule. In addition, the full width at half maximum (FWHM) of the $\left(\mathrm{d}_{001}\right)$ peak has declined by a slight way after silylation for modified bentonite Bent-APTMS (FWHM= $0.503)$ compared to natural bentonite $(\mathrm{FWHM}=0.349)$. This could be interpreted a slight decrease in the ordered. However, despite decrease in the ordered nature the structure of bentonite was preserved.

As indicated by the XRD analysis of modified bentonite, APTMS pillaring on the bentonite surface was successfully achieved.

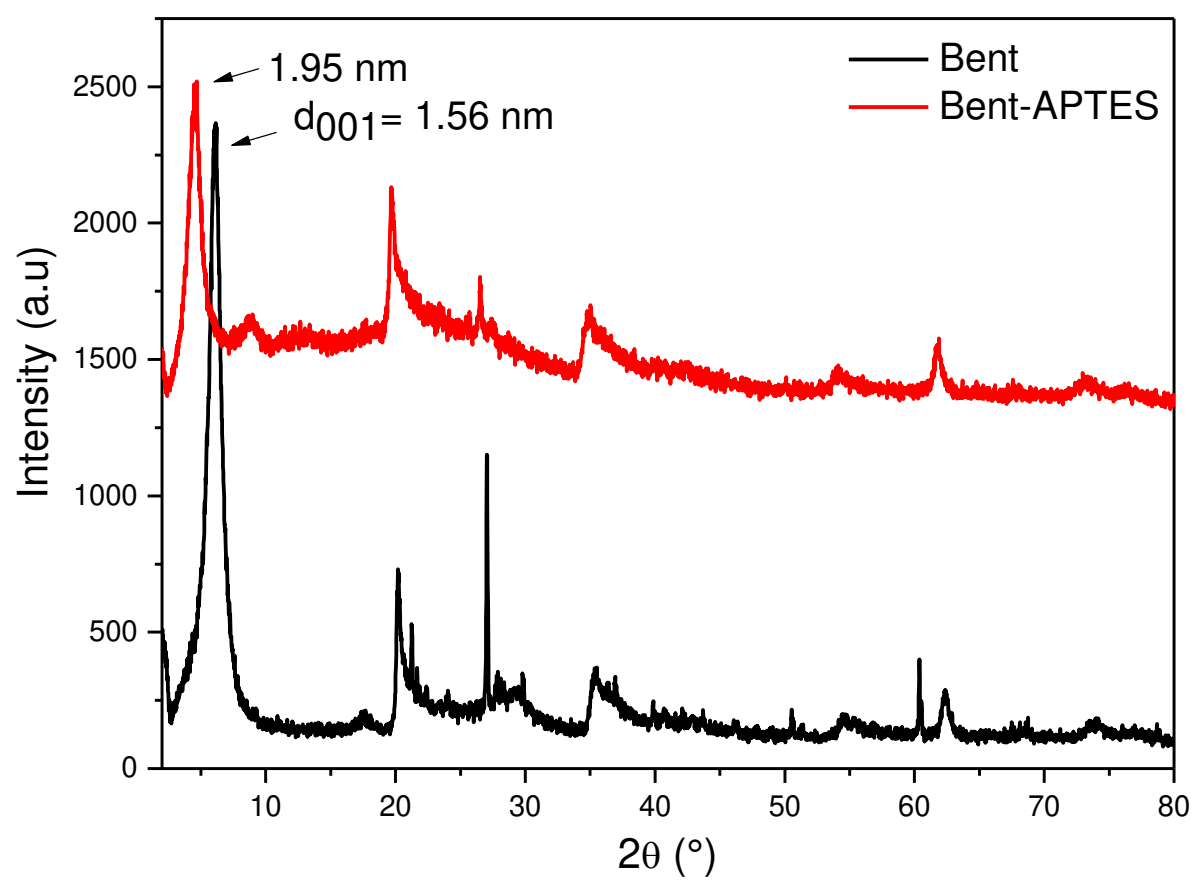

Fig. 1 TheXRD patterns of Bent and Bent-APTMS

\section{Fourier transform infrared spectroscopy (FTIR)}

Fig. 2 shows the FTIR spectra of the unmodified (Bent) and the silylated bentonite (Bent-APTMS). All spectra display typical absorption bands of Bent. The band about $3625 \mathrm{~cm}^{-1}$ is attributed to the $-\mathrm{OH}$ stretching vibration of the structural $-\mathrm{OH}$ groups in Bent. The broad bands in the region of 3000-3600 $\mathrm{cm}^{-1}$ and $\sim 1630 \mathrm{~cm}^{-1}$ are characteristic of the stretching and bending vibrations of adsorbed water. The strong absorption band situated about the $1000 \mathrm{~cm}^{-1}$ is a result of $\mathrm{Si}-\mathrm{O}-\mathrm{Si}$ stretching vibrations.

After silylation the spectrum of FTIR shows new bands; the peaks at 1132 and $1194 \mathrm{~cm}^{-1}$ are characteristics of $\mathrm{Si}-\mathrm{OCH}_{2} \mathrm{CH}_{3}$ (Vashist er al. 2014), the absorption bands at $\sim 2932$ and $\sim 2852 \mathrm{~cm}^{-1}$ correspond to the asymmetric and symmetric stretching vibrations of $-\mathrm{CH}_{2}-$, respectively (Tonle et al. 2003; Abeywardena et al. 2017). The band situated about the $3370 \mathrm{~cm}^{-1}$ and a shoulder at $\sim 3290$ may be assigned to the stretching vibrations of the $-\mathrm{NH}_{2}$ group (Abeywardena et al. 2017; Parolo et al. 2014). Furthermore, the decrease in peak intensities at $3635 \mathrm{~cm}^{-1}$ may be attributed to the hydrogen-bonding interaction between the APTMS and the $-\mathrm{OH}$ group. 


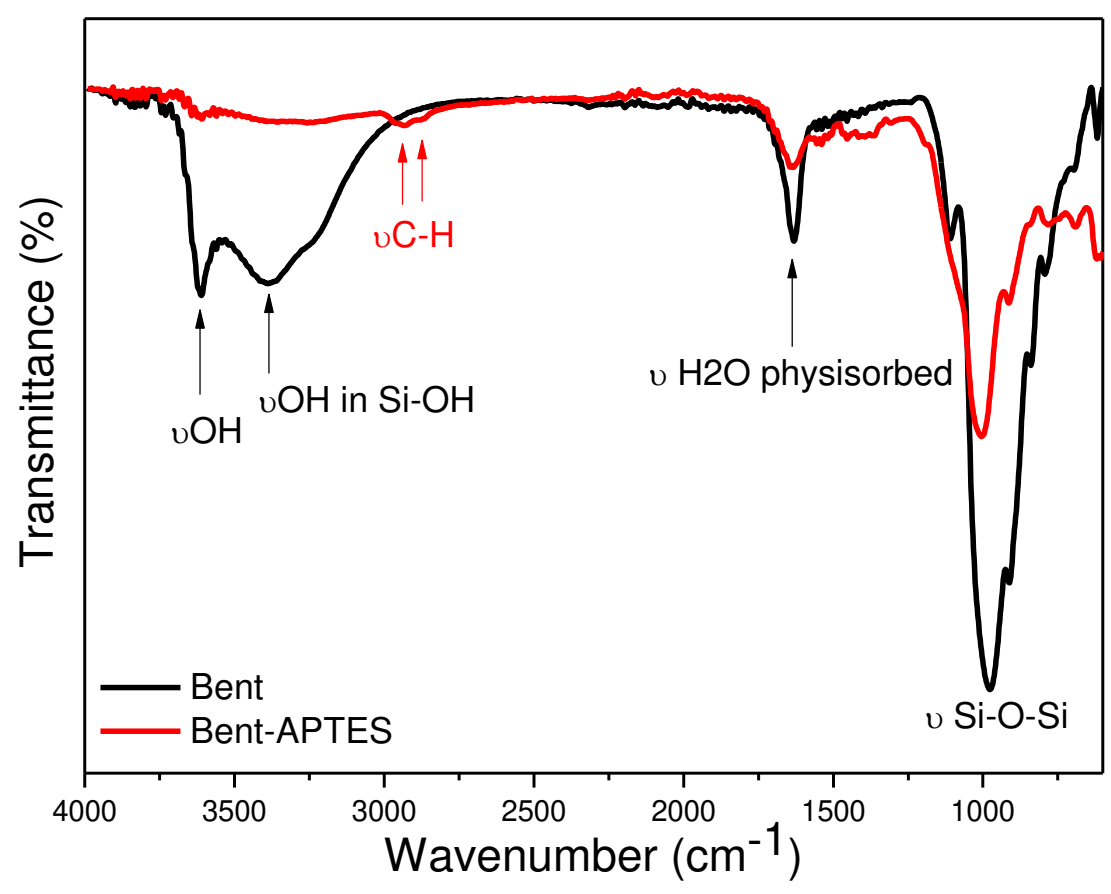

Fig. 2 FTIR spectra of unmodified Bent and silylated bentonite Bent-APTES

\section{Thermal analysis}

The thermal stability and the presence of organic molecule (APTMS) into the interlayer space of natural bentonite precursor are clearly shown using the thermograms of (TG) and derivative thermograms (DTG) which are presented in Fig. 3. The thermogravimetric analysis of the natural bentonite displays two region of the $56-110{ }^{\circ} \mathrm{C}$ and $480-510{ }^{\circ} \mathrm{C}$, assigned to the loss of the physically adsorbed water and the dehydroxylation of bentonite (Frost et al. 2000; Ding et al. 2004). However, the decomposition the modified bentonite Bent-APTMS shows six steps, such as demonstrated in DTG curve. The peaks about $100{ }^{\circ} \mathrm{C}$ is attributed to the loss of the physically adsorbed water (Frost et al. 2000). The peaks in the region of $225-580{ }^{\circ} \mathrm{C}$ are attributed to the decomposition of the intercalated silane in different nature (Su et al. 2012). It is noted that after silylation of the bentonite the DTG curve shows the increase of the temperature corresponding of decomposition of the dehydroxylation at $750{ }^{\circ} \mathrm{C}$. The silylation of bentonite increases the thermal stability of the clay. 

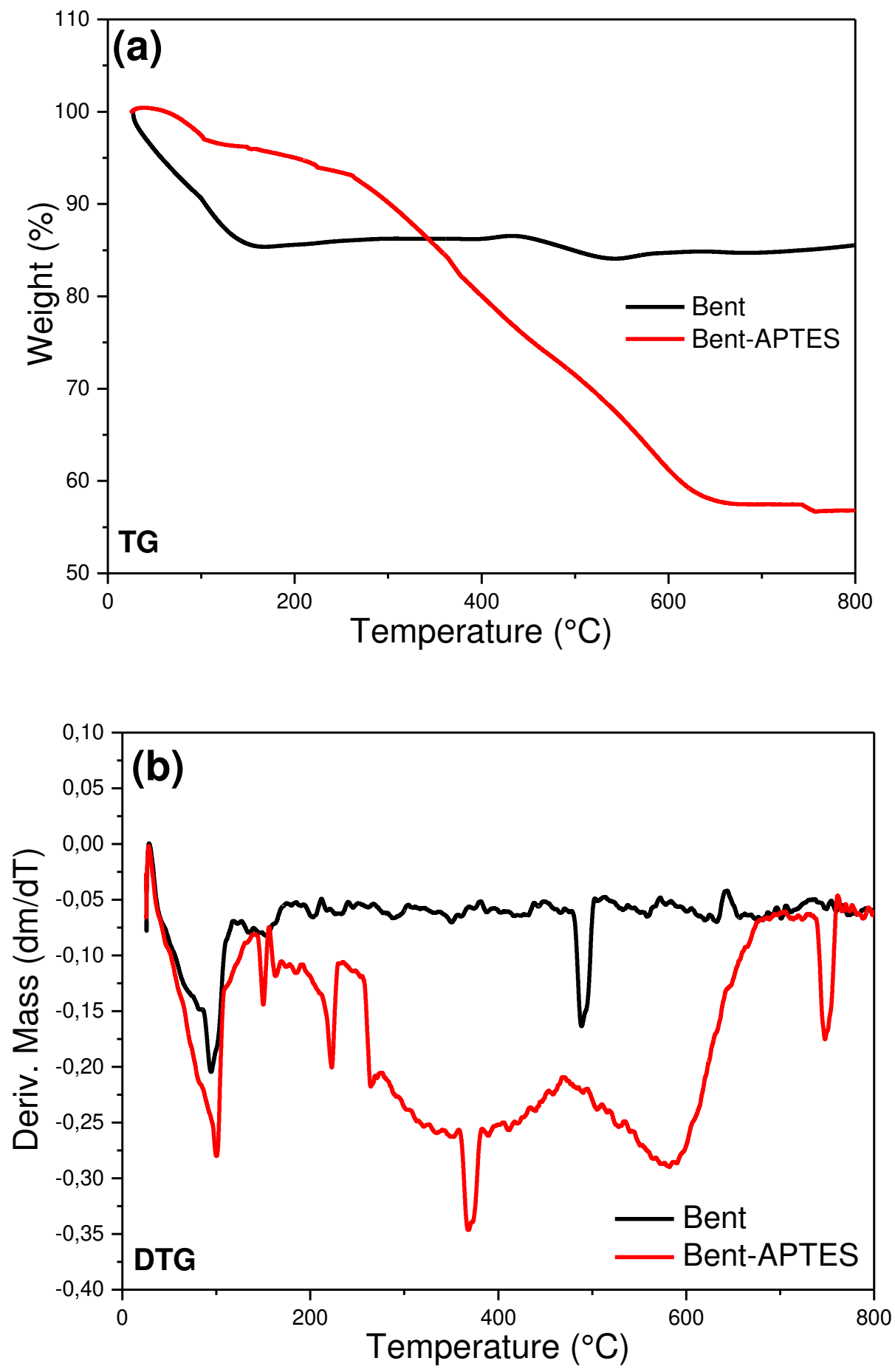

Fig. 3 TG (a) and DTG (b) curves of Bent and Bent-APTES

\section{Cation-exchange capacity (CEC)}

The material Bent-APTES has a CEC of the order of $31.03 \mathrm{meq} / 100 \mathrm{~g}$ of clay; it is significantly lower than that of the starting clay $(89.86 \mathrm{meq} / 100 \mathrm{~g})$. This decrease can be explained by the fact that the organosilicon oligomer initially fixed as a compensating cation occupies the exchange sites of the interlamellar space of the clay. 
As indicated by the XRD, FTIR, TGA and SEM analysis of modified bentonite, APTES pillaring on the bentonite surface was successfully achieved.

\section{Adsorption}

\section{Kinetic study of the adsorption}

Kinetic process gives fundamental knowledge about the interaction adsorbent-adsorbate. The kinetic adsorption evaluation of BM onto Bent-APTES (Fig. 4) was performed to establish its optimal time for adsorption. For MB, the adsorption is very rapid in the first $5 \mathrm{~min}$ and afterward, a very slow increase in the MB uptake is observed up to $20 \mathrm{~min}$. The rapid initial increase in the amount of adsorbed dye may be due to an increase in the number of vacant sites available at the beginning

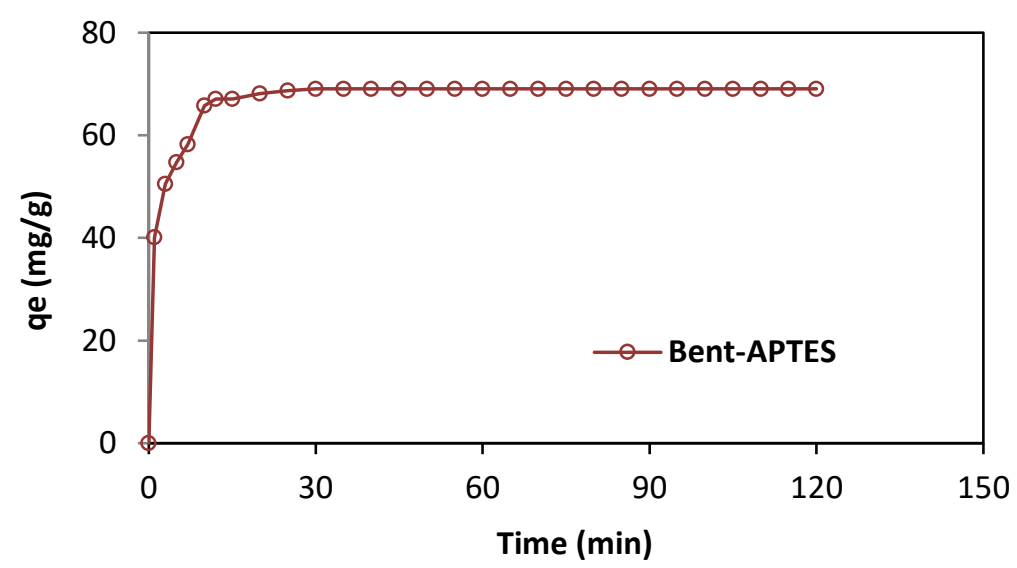

Fig. 4 The kinetic of MB removal onto Bent-APTES adsorbent

The first-order and the pseudo-second-order kinetic models were used to elucidate the adsorption mechanism.

The pseudo first-order kinetics model (Lagergren et al. 1898) is given by Eq. (3).

$$
\log \left(q_{e}-q_{t}\right)=\log q_{e}-\frac{k_{1} \cdot t}{2.303}
$$

where $q_{e}$ and $q_{t}(\mathrm{mg} / \mathrm{g})$ are the amounts of adsorbate adsorbed at equilibrium and at time $\mathrm{t}$, respectively, and $k_{1}\left(\mathrm{~min}^{-1}\right)$ is the rate constant of the first-order model.

The pseudo-second-order kinetic model (Ho and Ofomaja 2006) is expressed as Eq. (4):

$$
\frac{t}{q_{t}}=\frac{1}{k_{2} q_{e}^{2}}+\frac{1}{q_{e}} t
$$

where $\mathrm{k}_{2}(\mathrm{~g} / \mathrm{mg} \cdot \mathrm{min})$ is the constant rate of pseudo-second order adsorption. $q_{e}$ and $q_{t}(\mathrm{mg} / \mathrm{g})$ are the amounts of adsorbate adsorbed at equilibrium and at time $t$, respectively. 
The experimental data were fitted to pseudo-first-order (Fig. 5a) and pseudo second- order kinetic models (Fig. 5b) in order to investigate the mechanism of adsorption for the adsorptive removal of MB.

The kinetic parameters for the adsorption of dye on the clay minerals were calculated from the corresponding plots (Table 2). Correlation coefficients of the pseudo second-order kinetic model was relatively greater than that of the pseudo first order kinetic model, The calculated qe $\left(69.93 \mathrm{mg} \mathrm{g}^{-1}\right)$ was close to the experimental qe (69.05 $\left.\mathrm{mg} \mathrm{g}^{-1}\right)$, implying that the MB adsorption can be described more appropriately by the pseudo-second-order model. This result is in accordance with (Al-Futaisi et al. 2007), evidencing that the adsorption process occurred by a chemisorption mechanism. The fast removal of the dyes from solution, reaching the equilibrium in a rather short time, gave evidence that functionalized clay was efficient adsorbent.
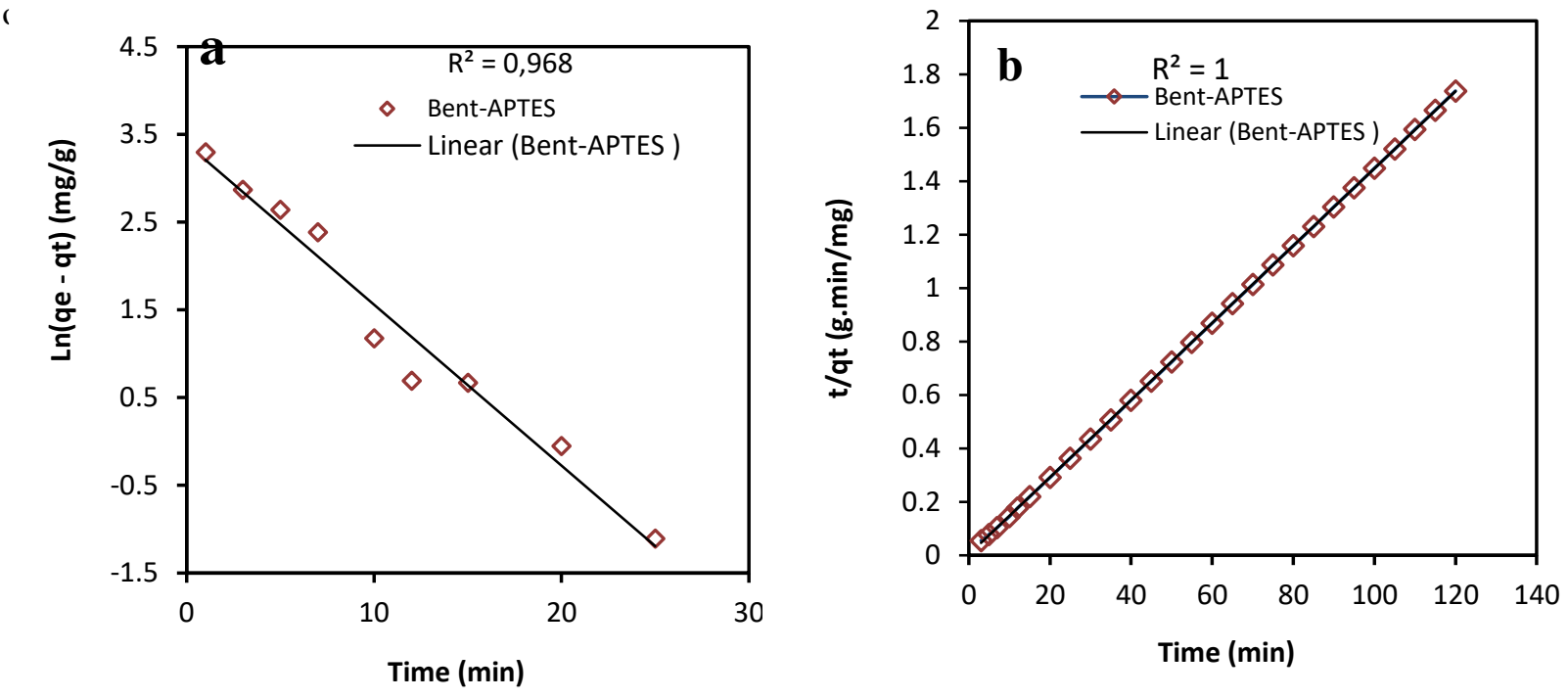

Fig. 5 Kinetics of MB removal onto Bent-APTES adsorbent, according to the pseudo first-order (a) and pseudo second-order (b) models

Table 2. Parameters of Kinetic Models for MB Removal by Bent-APTES

\begin{tabular}{|c|c|c|c|c|c|c|}
\hline \multirow[t]{2}{*}{ adsorbate } & \multicolumn{3}{|c|}{ pseudo-first-order model } & \multicolumn{3}{|c|}{ pseudo-second-order model } \\
\hline & $\mathrm{qe}(\mathrm{mg} / \mathrm{g})$ & $\mathrm{k}_{1}\left(\min ^{-1}\right)$ & $\mathrm{R}^{2}$ & $\mathrm{qe}(\mathrm{mg} / \mathrm{g})$ & $\mathrm{K}_{2}\left(\mathrm{~g} \mathrm{mg}^{-1} \mathrm{~min}^{-1}\right)$ & $\mathrm{R}^{2}$ \\
\hline MB & 25,725 & 0,183 & 0,968 & 69,93 & 0,068 & 1,000 \\
\hline
\end{tabular}

\section{Effect of pH on MB Absorption}

The effect of initial $\mathrm{pH}$ on the adsorption capacity (qt) of MB onto Bent-APTES was examined at different levels ( $\mathrm{pH} 3-11$ ) by fixing other parameters, as shown in Fig. 6a. However, as illustrated in Fig. 
6a, MB uptake $\left(q_{e}\right)$ onto Bent-APTES was not considerably affected by $\mathrm{pH}$ because of the buffering effect of the adsorbent. There are similarity results about the effect of $\mathrm{pH}$ on the organic cation adsorption in the literature. For example, (Narine et al. 1981) have reported that the adsorption capacity of bentonite was unchanged over the $\mathrm{pH}$ range 4.5-8.5. On the other hand, Similar tendencies were also reported for the cationic dye adsorption by montmorillonite, palygorskite, bentonite and sepiolite (Roulia et al. 2008; Al-Futaisi et al. 2007; Bilgiç et al. 2005).

\section{Effect of Adsorbent Dosage on MB Absorption}

To obtain a cost-optimal adsorption of dyes and heavy metal species from wastewater, the minimum adsorbent dosage that ensures efficient removal of contaminants is usually determined. The influence of different Bent-APTES dosages on MB removal within $30 \mathrm{~min}$ of contact time is illustrated in Fig. $6 \mathrm{~b}$. According to Fig. 6b, with an increase in the adsorbent dosage from 0.5 to $1 \mathrm{~g} \mathrm{~L}^{-1}$, the elimination of MB increases. This finding may be related to active adsorption sites, which facilitate and prompt the adsorption reaction. Though higher Bent-APTES dosages provided a high efficiency of MB removal, the successive addition of the Bent-APTES dosage to above $1 \mathrm{~g} \mathrm{~L}^{-1}$ did not promote the MB elimination significantly. Therefore, $1 \mathrm{~g} \mathrm{~L}^{-1}$ Bent-APTES could be selected as the optimum.
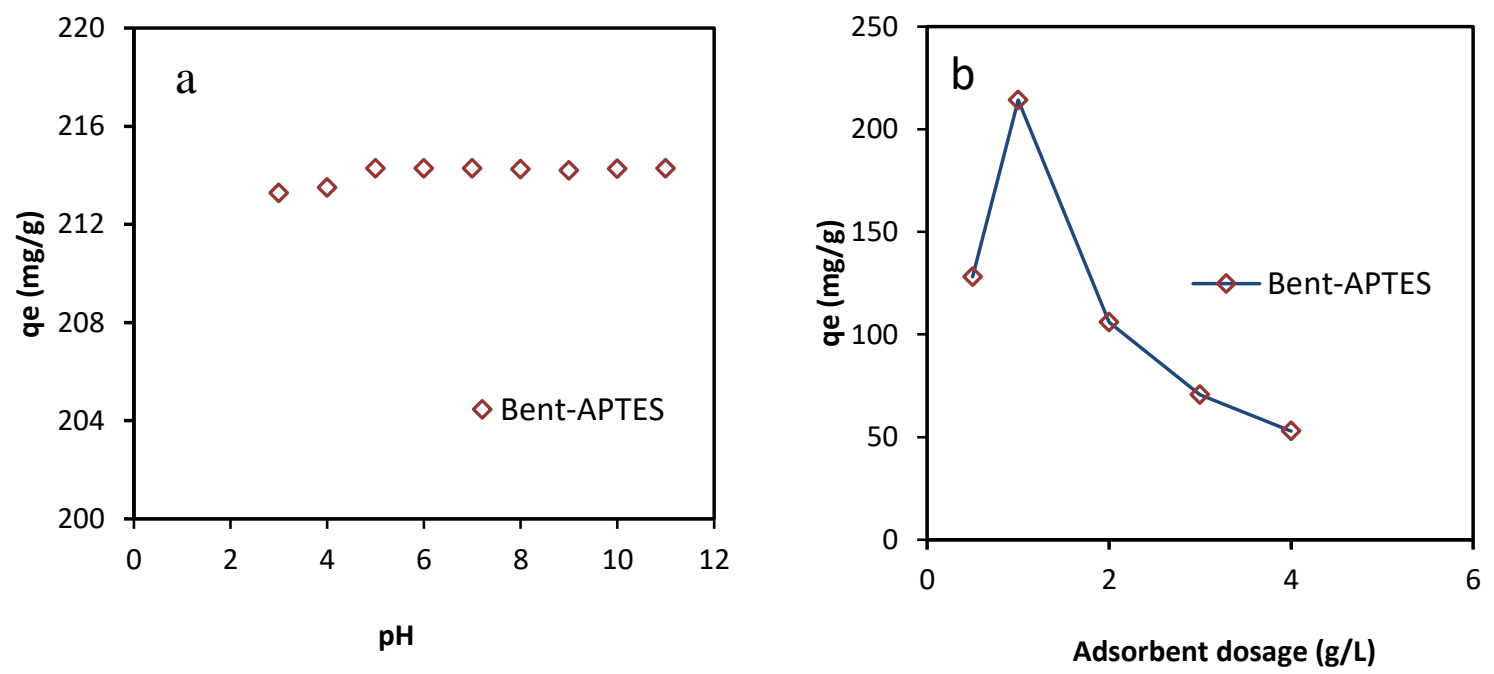

Fig. 6 Effect of of $\mathrm{pH}(\mathrm{a})$, and sorbent on sorption of MB onto Bent-APTES.

\section{Isotherm models}

The sorption behaviors of MB onto Bent-APTES adsorbent were investigated. In this study, two isotherm models as the most widely used models were tested to fit the data including Freundlich (Freundlich 1907) and Langmuir (Langmuir 1918). 
Langmuir model assumes that a reversible sorption process occurs on a homogenous surface forming a monolayer sorption without interactions between the adsorbed specie onto the adsorbate. The Langmuir isotherm adsorption equation is expressed as eq. 5 .

$$
\frac{C_{e}}{q_{e}}=\frac{1}{q_{m} K_{L}}+\frac{C_{e}}{q_{m}}
$$

where $\mathrm{q}_{\mathrm{e}}(\mathrm{mg} / \mathrm{g})$ is the quantity of metal ions $(\mathrm{mg})$ adsorbed per gram of solid, from the aqueous solution; $C_{e}(\mathrm{mg} / \mathrm{L})$ is the equilibrium concentration of metal ions in aqueous solution; $\mathrm{K}_{\mathrm{L}}$ is the Langmuir equilibrium constant and $\mathrm{q}_{\mathrm{m}}(\mathrm{mg} / \mathrm{g})$ is the maximum adsorption capacity. Both of them are calculated from the slope and the intercept of Langmuir linearized plot (Fig.7a), $C_{e} / q_{e}$ vs. $C_{e}$.

Freundlich model assumes that the surface has active sites with different affinity for the adsorbate. The sites with higher affinity would be covered firstly. The linear form of the Freundlich model is given by eq 6:

$$
\log q_{e}=\frac{1}{n} \log C_{e}+\log K_{F}
$$

where $q_{e}(\mathrm{mg} / \mathrm{g})$ is the quantity of metal ions $(\mathrm{mg})$ adsorbed, per gram of solid, from the aqueous solutions. $C_{e}(\mathrm{mg} / \mathrm{l})$ is the equilibrium concentration of metal ions in aqueous solution. $\mathrm{n}$ and $\mathrm{K}_{\mathrm{F}}$ are the Freundlich constants. Both are calculated from the linear plot of $\log q_{e}$ vs. $\log C_{e}$ (Fig. 7b).

The calculated parameters for two isotherm models are listed in Table 3. The $q_{m}$ (maximum adsorption capacity) values obtained by calculation and experiment were 217,391 and $214.280 \mathrm{mg} \mathrm{g}^{-1}$, respectively. According to results of the table 3, it is obvious that Langmuir model presented the best regression coefficient $\left(\mathrm{R}^{2}>0.99\right)$ compared to the Freundlich isotherm model (Table 3), indicating that MB was adsorbed on Bent-APTES as a monolayer adsorption.
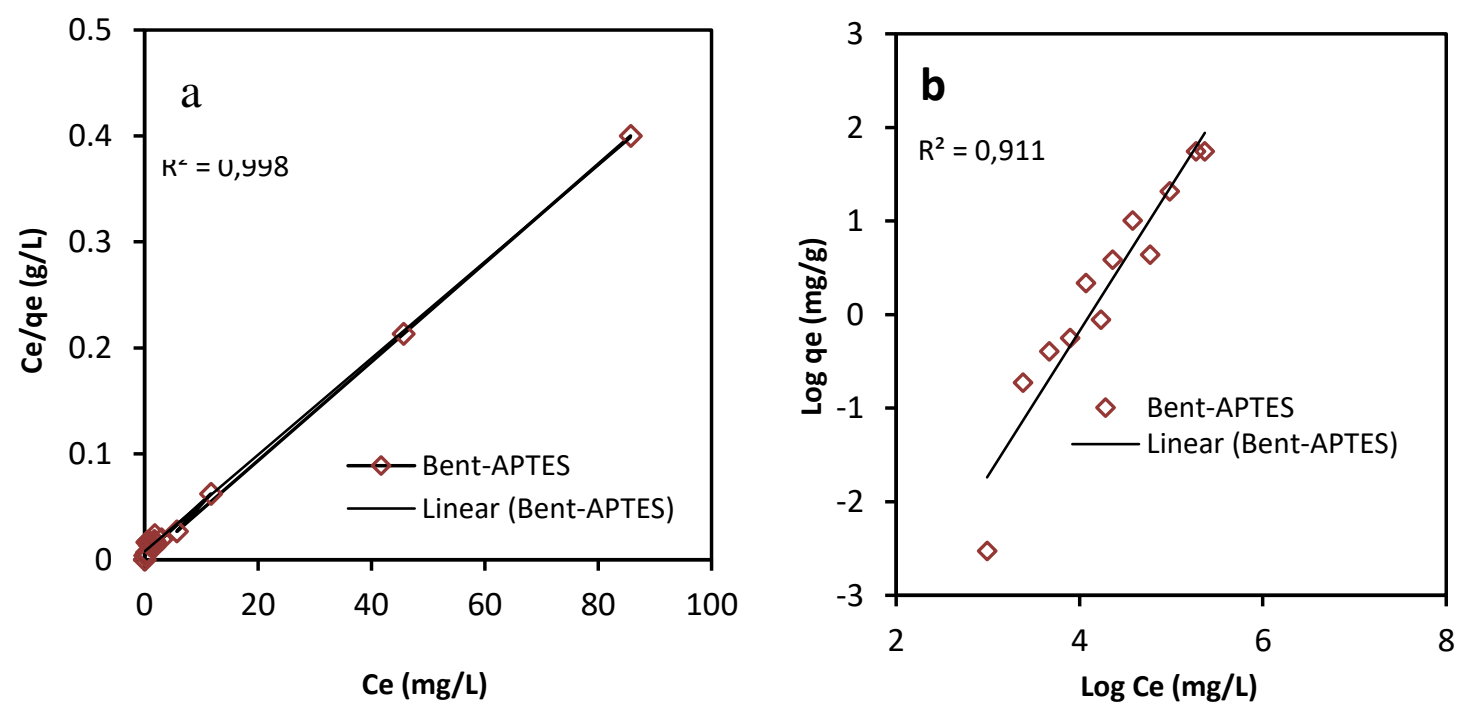

Fig.7 Langmuir model (a), and Freundlich model (b) for MB sorption onto Bent-APTES 
Table 3 Parameters of Isotherm Models for MB Removal from Solution by Bent-APTES

\begin{tabular}{lllllll}
\hline & \multicolumn{3}{l}{ Langmuir isotherm model } & \multicolumn{3}{l}{ Freundlich isotherm model } \\
\hline adsorbate & $\mathrm{q}_{\mathrm{m}}(\mathrm{mg} / \mathrm{g})$ & $\mathrm{K}_{\mathrm{L}}(\mathrm{L} / \mathrm{mg})$ & $\mathrm{R}^{2}$ & $\mathrm{n}$ & $\mathrm{K}_{\mathrm{f}}(\mathrm{mg} / \mathrm{g})$ & $\mathrm{R}^{2}$ \\
\hline MB & 217.391 & 0.657 & 0.998 & 1.549 & 0.0017 & 0.911 \\
\hline
\end{tabular}

\section{Comparison of Bent-APTES with other adsorbents}

Adsorption capacities of various adsorbents towards methylene blue dye as reported in literature were presented in Table 4.

A comparison between this work and other reported data from the literature shows that bentonite functionalized with 3-aminopropyltriethoxysilane is a better adsorbent for methylene blue compared to other adsorbents. Therefore, it could be safely concluded that the Bent-APTES adsorbent has a considerable potential for the removal of methylene blue from an aqueous solution.

Table 4 Comparison of the maximum adsorption capacity of MB on some natural and synthetic adsorbents from aqueous solution

\begin{tabular}{llc}
\hline Material & \multicolumn{1}{c}{$(\mathrm{mg} / \mathrm{g})$} & References \\
\hline spent activated clay & 91.134 & [Smithetb al. 2016] \\
sodalite & 45.46 & [Borhade al. 2017] \\
Safi decanted clay (SDC) & 114.16 & oubarki al. 2015] \\
Bentonite (UB) & 38.0228 & [Bilgiç et al 2005] \\
Bentonite saturated with sodium & 48.3091 & [Bilgiç et al 2005] \\
Bentonite saturated with calcium & 43.5161 & [Bilgiç et al 2005] \\
Chitin/clay microspheres & 152.20 & [Xu et al 2018] \\
Magnetic halloysite-chitosan (MHNT-CTN) & 50.370 & Türkeş and Sağ Açıel 2020] \\
Bent-APTES & 217.39 & Present study \\
\hline
\end{tabular}

\section{Conclusion}

In this study, 3-aminopropyltriethoxysilane was used to functionalize bentonite clay in order to remove methylene blue from aqueous solutions. The characterization data indicated remarkable differences between functionalized and non-functionalized clay highlighting the successful intercalation process.

These modified clay exhibited great ability for removal of methylene blue (MB) from wastewater. The effects of contact time, initial dye concentration, $\mathrm{pH}$ value, and adsorbent mass on the adsorption process were discussed. Sorption of MB onto Bent-APTES was spontaneous monolayer adsorption, which could be well described by pseudo-second order and Langmuir isotherm models. With these findings, this work may promote the development of new absorbents for the removal of dye from wastewater. 


\section{References}

Abeywardena SBY, Perera S, Nalin de Silva KM, Tissera NP (2017) A facile method to modify bentonite nanoclay with silane. Int Nano Lett 7(3):237-241. https://doi.org/10.1007/s40089-017-0214-2

Al-Futaisi A, Jamrah A, Ai-Hanai R (2007) Aspects of cationic dye molecule adsorption to palygorskite. Desalination 214 (1-3):327-342. https://doi.org/10.1016/j.desal.2006.10.024

Belhadri M, Mokhtar A, Meziani S, Belkhadem F, Sassi M, Bengueddach A (2019) Novel low-cost adsorbent based on economically modified bentonite for lead(II) removal from aqueous solutions. Arab J Geosci 12:88. https://doi.org/10.1007/s12517-019-4232-4

Bertuoli PT, Piazza D Scienza LC, Zattera AJ (2014) Preparation and characterization of montmorillonite modified with 3-aminopropyltriethoxysilane. Appl. Clay Sci., 87, 46-51. doi:10.1016/j.clay.2013.11.020

Borhade AV, Kshirsagar TA; Dholi AG (2017) Eco-Friendly Synthesis of Aluminosilicate Bromo Sodalite fromWaste Coal Fly Ash for the Removal of Copper and Methylene Blue Dye. Arab J Sci Eng 42:4479-4491. DOI 10.1007/s13369-017-2759-9

Chen Y, Yu G, Li F, Severance M (2013) Synthesis and visible-light photochromism of a new composite based on polymolybdate enclosed in magadiite. Inorg. Chem 52(13):7431-7440. https://doi.org/10.1021/ic400569y

Chiu YC, Huang LN, Uang CM, Huang JF (1990). Determination of cation exchange capacity of clay minerals by potentiometric titration using divalent cation electrodes. Colloids Surf 46 (2):327-337. https://doi.org/10.1016/0166-6622(90)80174-3

Elmoubarki R, Mahjoubi F, Tounsadi H, Moustadraf J, Abdennouri, M, Zouhri A, El Albani A, Barka N (2015) Adsorption of textile dyes on raw and decanted Moroccan clays: kinetics, equilibrium and thermodynamics. Water Res Ind 9:16-29. https://doi.org/10.1016/j.wri.2014.11.001

Endo T, Mortland MM, Pinnavaia TJ (1981) Properties of silica-intercalated hectorite. Clays Clay Miner 29 (2):153-156. https://doi.org/10.1346/CCMN.1981.0290210

Fetter G, Tichit D, Massiani P, Dutartre R, Figueras F (1994) preparation and characterization of montmorillonites pillared by cationic silicon species. Clay Clay Miner 42 (2):161-169. https://doi.org/10.1346/CCMN.1994.0420206

Freundlich H (1906) Uber die adsorption in losungen. Z Phys Chem 57. https://doi.org/10.1515/zpch$1907-5723$ 
Frost RL, Ruan, H, Theo Kloprogge J, Gates W (2000) Dehydration and dehydroxylation of nontronites and ferruginous smectite. Thermochim Acta 346(1-2):63-72. https://doi.org/10.1016/S00406031(99)00366-4

He H, Frost RL, Deng F, Zhu J, Wen X, Yuan P (2004) Conformation of Surfactant Molecules in the Interlayer of Montmorillonite Studied by ${ }^{13} \mathrm{C}$ MAS NMR. Clay Clay Miner 52(3):350-356. https://doi.org/10.1346/CCMN.2004.0520310

He H, Duchet J, Galy J, Gerard J.-F. (2005). Grafting of swelling clay materials with 3aminopropyltriethoxysilane. J Colloid Interface $\quad$ Sci 176. doi:10.1016/j.jcis.2005.02.092

Huskić M, Žigon M, Ivanković M (2013) Comparison of the properties of clay polymer nanocomposites prepared by montmorillonite modified by silane and by quaternary ammonium salts. Appl Clay Sci 85: 109-115. https://doi.org/10.1016/j.clay.2013.09.004

Ho Y, Ofomaja A (2006) Pseudo-second-order model for lead ion sorption from aqueous solutions onto palm kernel fiber. J Hazard. Mater 129(1-3) :137-142. doi:10.1016/j.jhazmat.2005.08.020

Kausar A, Iqbal M, Javed A, Aftab K, Nazlia Z-i-H., Bhatti HN, Nouren S (2018) Dyes adsorption using clay and modified clay: A review. J Mol Liq 256:395-407. https://doi.org/10.1016/j.molliq.2018.02.034

Lagergren S (1898) About the theory of so-called adsorption of soluble substances. K Sven Vetensk.akad Handl 24:1-39

Langmuir I (1918) The adsorption of gases on plane surfaces of glass, mica and platinum. J Am Chem Soc 40(9):1361-1403. https://doi. org/10.1021/ja02242a004

Mondal B, Srivastava VC, Kushwaha JP, Bhatnagar R, Singh S, Mall ID (2013) Parametric and multiple response optimization for the electrochemical treatment of textile printing dye-bath effluent. Sep Purif Technol 109:135-143. https://doi.org/10.1016/j.seppur.2013.02.026

Narine DR, Guy RD (1981) Interactions of Some Large Organic Cations with Bentonite in Dilute Aqueous Systems. Clay 29:205-212. https://doi.org/10.1346/CCMN.1981.0290306

Parolo ME, Pettinari GR, Musso TB, Sánchez-Izquierdo MP, Fernández LG (2014) Characterization of organo-modified bentonite sorbents: The effect of modification conditions on adsorption performance. Appl Surf Sci 320:356-363. 5 https://doi.org/10.1016/j.apsusc.2014.09.10 
Peech M, Cowan RL, Baker JH (1962) A Critical Study of the $\mathrm{BaCl}_{2}$-Triethanolamine and the Ammonium Acetate Methods for Determining the Exchangeable Hydrogen Content of Soils. Soil Sci Soc Am J 26 (1): 37-40. https://doi.org/10.2136/sssaj1962.03615995002600010010x

Roulia M, Vassiliadis AA (2008)Sorption characterization of a cationic dye retained by clays and perlite Micropor. Mesopor. Mat., 116(1-3), 732-740. doi:10.1016/j.micromeso.2008.03.017

Smith YR, Bhattacharyya D, Willhard T, Misra M (2016) Adsorption of aqueous rare earth elements using carbon black derived from recycled tires. Chem Eng J 296:102-111. https://doi.org/10.1016/j.cej.2016.03.082

Ruiz-Hitzky E, Fripiat JJ (1976) Organomineral derivatives obtained by reacting organochlorosilanes with the surface of silicates in organic solvents. Clays Clay Miner 24(1): 25-30.

Russo V, Masiello D, Trifuoggi M, Di Serio, M, Tesser R (2016) Design of an adsorption column for methylene blue abatement over silica: from batch to continuous modeling. Chem Eng J 302:287295. https://doi.org/10.1016/j.cej.2016.05.020

Shen W, He H, Zhu J, Yuan P, Frost, RL (2007) Grafting of montmorillonite with different functional silanes via two different reaction systems. J Colloid Interf Sci., 313(1), 268273. doi:10.1016/j.jcis.2007.04.029

Su L, Tao Q, He H, Zhu J, Yuan P (2012) Locking effect: A novel insight in the silylation of montmorillonite surfaces. Mater Chem. Phys 136(2-3):292-295. https://doi.org/10.1016/j.matchemphys.2012.07.010.

Tao Q, Zhu J, Wellard RM, Bostrom TE, Frost RL, Yuan P, He H (2011) Silylation of layered double hydroxides via an induced hydrolysis method. J Mater Chem 21(29):10711. https://doi.org/10.1039/C1JM10328H.

Tonle, IK, Ngameni E, Njopwouo D, Carteret C, Walcarius A (2003) Functionalization of natural smectite-type clays by grafting with organosilanes: physico-chemical characterization and application to mercury(II) uptake. Phys Chem Chem Phys 5(21):4951. https://doi.org/10.1039/B308787E

Türkeş E, Sağ Açıke Y (2020) Synthesis and characterization of magnetic halloysite-chitosan nanocomposites: use in the removal of methylene blue in wastewaters Int J Environ Sci Technol 17:1281-1294. https://doi.org/10.1007/s13762-019-02550-W 
Vashist SK, Lam E, Hrapovic S, Male KB, Luong JHT (2014). Immobilization of Antibodies and Enzymes on 3-Aminopropyltriethoxysilane-Functionalized Bioanalytical Platforms for Biosensors and Diagnostics. Chem Rev 114(21) :11083-11130. doi:10.1021/cr5000943

Vergili I, Kaya Y, Sen U, Gönder ZB, Aydiner C (2012) Technoeconomic analysis of textile dye bath wastewater treatment by integrated membrane processes under the zero liquid discharge approach. Resour Conserv Recycl 58:25-35. https://doi.org/10.1016/j.resconrec.2011.10.005

Verma AK, Dash RR, Bhunia P (2012) A review on chemical coagulation/flocculation technologies for removal of colour from textile wastewaters. J Environ Manage 93:154-168 https://doi.org/10.1016/j.jenvman.2011.09.012

Waddell TG, Leyden DE, DeBello MT (1981) The nature of organosilane to silica-surface bonding. $J$ Am Chem Soc 103(18):5303-5307. https://doi.org/10.1021/ja00408a005

Weng C-H, Pan Y-F (2007) Adsorption of a cationic dye (methylene blue) onto spent activated clay. J Hazard Mater 144:355-362. https://doi.org/10.1016/j.jhazmat.2006.09.097

Xi Y, Ding Z, He H, Frost RL (2004). Structure of organoclays-an X-ray diffraction and thermogravimetric analysis study. J Colloid Interface Sci, 277(1):116-120. doi: 10.1016/j.jcis.2004.04.053

Xu R, Mao J, Peng N, Luo X, Chang C (2018)Chitin/clay microspheres with hierarchical architecture for highly efficient removal of organic dyes Carbohydr. Polym. 188, 143. https://doi.org/10.1016/j.carbpol.2018.01.073

Yagub MT, Sen TK, Afroze S, Ang HM (2014) Dye and its removal from aqueous solution by adsorption: a review. Adv Colloid Interf Sci 209:172-184. https://doi.org/10.1016/j.cis.2014.04.002

Zhang J, Gupta RK, Wilkie CA (2006) Controlled silylation of montmorillonite and its polyethylene nanocomposites. Polymer 47(13): 4537-4543. https://doi.org/10.1016/j.polymer.2006.04.057 